\title{
TEKNOLOGI PEMBUATAN KOMPOS KOTORAN SAPI SIMENTAL DENGAN PENGGUNAAN TITHONIA (Thitonia diversifolia) DAN MOL REBUNG PADA KELOMPOK TANI TERNAK
}

\author{
Ade Rakhmadi, Allismawita dan Indri Juliyarsi \\ Fakultas Peternakan Universitas Andalas \\ .Email : aderakhmadi@gmail.com
}

Received: 01 Juli 2018. Accepted: 18 Agustus 2018. Published Online 1 September 2018

\begin{abstract}
ABSTRAK
Kompos merupakan pupuk organik yang mudah didapatkan. Dalam pembuatannya membutuhkan waktu 4-6 bulan.Hal ini dapat dipersingkat dengan pemakaian starter kompos seperti EM4 dan stardex.Akan tetapi starter kompos ini berharga mahal dan sulit didapatkan. Untuk itu maka MOL (Mikro Organisme Lokal) Rebung dapat menggantikan starter yang mahal. Selain harga yang murah, MOL Rebung ini mudah dibiakkan. Kotoran sapi Simmental merupakan bahan baku pembuatan pupuk kompos. Akan tetapi masih mempunyai unsur hara yang rendah.Untuk itu ditambahkan tithonia sebagai penambah unsur haranya.Penyuluhan di Kanagarian Koto Baru mendapat antusias yang besar dari masyarakat, karena masyarakat sangat membutuhkan pupuk kompos. Dalam penyuluhan masyarakat diajarkan dalam memperbanyak starter MOL dari Rebung. Perbanyakan starter ini menggunakan rebung, gula merah dan air cucian beras sebagai medianya.
\end{abstract}

Kata Kunci: kompos, MOL rebung, simmental, tihonia

\section{Technology of Making Sim Cow Manure Simental using Tithonia (Thitonia Diversifolia) And Mol Rebung On Livestock Farming Group}

\begin{abstract}
Compost is an easy organic fertilizer. In the making takes 4-6 months. This can be shortened by the use of compost starters such as EM4 and stardex. However, this compost starter is expensive and difficult to obtain. For that then MOL (Micro Organism Local) Rebung can replace the starter is expensive. In addition to low prices, MOL Rebung is easily bred. Simmental cattle dung is the raw material of compost fertilizer. However, it still has a low nutrient. For that plus tithonia as an addition element haranya. Counseling in Kanagarian Koto Baru get great enthusiasm from the community, because the community is in dire need of compost. In counseling the community is taught to multiply the MOL starter from Rebung. This starter propagation uses bamboo shoots, brown sugar and rice washing water as the medium.
\end{abstract}

Keyword : compos, MOL Rebung, Simmental, Tihonia

\section{PENDAHULUAN}

Kabupaten Tanah Datar merupakan suatu Kabupaten yang dulunya berpusat dari kerajaan Minang Kabau, sehingga tatanan sosial dan budaya Minangkabau Asli masih tetap dijumpai diseluruh wilayah kabupaten ini. Secara geografis wilayah Kabupaten Tanah Datar terletak ditengah-tengah profinsi Sumatera Barat, yaitu pada $00^{\circ} 17^{\prime}$ " Lintang Selatan - 00³9" Lintang Selatan dan 100¹9" - 10051" Bujur Timur. Ketinggian rata-rata 400 -1000 m DPL, luas wilayah $133.600 \mathrm{Ha}$. Batas - batas wilayah 
Kabupaten Tanah Datar yaitu:

1. Sebelah Utara berbatasan dengan Kabupaten Agam dan 50 Kota

2. Sebelah Selatan berbatasan dengan Kabupaten Solok

3. Sebelah Barat berbatasan dengan Padang Pariaman

4. Sebelah Timur berbatasan dengan Kota Sawahlunto dan Kabupaten Sijunjung.

Secara umum iklimnya sedang dengan temperatur antara $12^{\circ} \mathrm{C}-25^{\circ} \mathrm{C}$, dengan curah hujan rata - rata lebih dari $3.000 \mathrm{~mm}$ per tahun. Hujan kebanyakan turun pada bulan September hingga bulan februari. Curah hujan yang cukup tinggi ini menyebabkan ketersediaan cukup air sehingga memungkinkan usaha pertanian secara luas dapat dikembangkan.

Kabupaten Tanah Datar terdiri dari 14 kecamatan masing - masing adalah kecamatan Sepuluh Koto, Batipuh, Batipuh Selatan, Pariangan, Rambatan,Limo Kaum, Sungai Tarab, Salimpauang, Tanjuang Baru, Sungayang, Tanjung Emas, Padang Gantiang, Lintau Buo, dan Lintau Buo Selatan.

Kenagarian Koto Baru mempunyai luas daerah 414 ha dan akses jalan yang dapat dilalui kendaraan roda empat dan enam. Jarak ke Ibukota Kecamatan $6 \mathrm{~km}$, kota Kabupaten $10 \mathrm{~km}$ dan kota propinsi $112 \mathrm{~km}$. jalan ini sangat penting artinya bagi masyarakat yang sebagian besar adalah berpendapatan sebagai petani dan ada juga sebagai peternak. Dari berbagai ternak yang dipelihara yang lebih menonjol adalah kerbau, sapi potong dan ayam kampung. Setiap kandang sapi / kerbau umumnya memelihara 3-5 ekor dan ayam 10-50 ekor. Untuk lebih jelasnya populasi ternak dikanagarian ini ditampilkan pada Tabel 1.

Tabel 1. Populasi Ternak Kenagarian Koto Baru

\begin{tabular}{lc}
\hline Jenis Ternak & Jumlah (ekor) \\
\hline Kerbau & 80 \\
Sapi potong & 50 \\
Kambing & 58 \\
Ayam kampung & 200 \\
Itik & 400 \\
\hline
\end{tabular}

Peningkatan populasi sapi potong maka akan menghasilkan limbah ternak sapi yang apabila tidak ditangani dengan baik akan mengakibatkan pencemaran udara dan air. Kondisi ini dikarenakan pengetahuan petani peternak tentang pengolahan limbah belum optimal, sehingga limbah ini terbuang dengan percuma.

Kotoran ternak merupakan bahan pembuat pupuk organik yang sangat bagus, karena merupakan limbah organik yang banyak mengandung protein.Limbah ternak mengandung nutrisi yang baik untuk pertumbuhan tanaman (Djuarnani dkk, 2005). Dalam pembuatan pupuk organik, terjadi proses fermentasi atau dekomposisi yang dilakukan oleh mikroorganisme pengurai.

Pupuk organik dari kotoran ternak mempunyai kandungan unsur hara yang masih rendah yaitu $1.26 \% \mathrm{~N}, 1.03 \% \mathrm{P}_{2} \mathrm{O}_{5}, 1.07 \% \mathrm{~K}_{2} \mathrm{O}$ (Syahruddin, 2006), sehingga perlu dilakukan peningkatan unsur haranya.Peningkatan unsur hara ini dapat dilakukan dengan menambah kantanaman Tithonia (Tithonia diversifolia), atau dikenal dengan bunga matahari meksiko.Bunga matahari meksiko berpotensi digunakan sebagai pupuk hijau, karena mengandung unsur hara yang tinggi yaitu sekitar $3.5-4.0 \% \mathrm{~N}, 0.35-$ 
0.38\% P, 3.5-4.1\% K,0.59\% Ca dan 0.27\% Mg. (Jama dkk, 2000). Tanaman bunga matahari meksiko ini tersebar dikanagarian Koto Baru sehingga dapat dimanfaatkan dengan maksimal tanpa membutuhkan biaya tambahan.

Kompos memerlukan fermentasi atau dekomposisi dalam pembuatannya.Secara alami membutuhkan waktu yang sangat lama untuk prosesnya.Untuk mempercepat prosesnya biasanya masyarakat menambahkan stardec / EM4 dalam prosesnya.EM4 adalah bakteri pengurai bahan organik yang khusus digunakan dalam pembuatan kompos. Karena EM4 atau Stardec membutuhkan dana yang besar dalam pembuatan pupuk maka fungsi EM4 ini dapat digantikan oleh MOL (mikroorganisme lokal) Rebung.

Selain banyaknya popolasi ternak, Kenagarian Koto baru juga sebagai kenagarian penghasil rebung. Selama ini rebung hanya digunakan sebagai makanan. Padahal rebung menyimpan potensi probiotik yang sangat besar. Diantaranya mempunyai bakteri probiotik Lactobacillus plantarum .Bakteri ini dapat digunakan sebagai starter pembuatan pupuk.

Petani peternak Kanagarian Koto Baru merupakan peternak tradisional.Selama ini limbah feces ternak dikenagarian banjaloweh ini belum termanfaatkan dengan baik .Padahal dengan bantuan teknologi feces ini dapat termanfaat kandengan baik dan mempunyaidaya jual yang tinggi.Sebagai contoh dikanagarian Salimpauang Kab Tanah Datar, limbah feces ternak ini termanfaatkan dengan baik melalui pembuatan biogas dan pupuk kompos yang sudah mulai diperjual belikan seharga Rp.1600.- / kg.

\section{METODE}

Metodologi dari kegiatan ini adalah metode penyuluhan dan pelatihan. Masyarakat dan mitra (petani peternak) akan diberikan penyuluhan dan pelatihan mengenai cara pengolahan feces sapi menjadi kompos dengan penambahan tithonia dan pembuatan MOL Rebung. Pelatihan itu antara lain mengenai pengenalan limbah hasil ternak dan teknologi pengolahannya. Masyarakat dan mitra juga dibimbing dalam pemasarannya. Adapun luaran yang diharapkan adalah sebagai berikut:

\section{Pembuatan MOL Rebung Sebagai Starter.}

- Rebung bambu disiapkan sebanyak 1000 gram yang ditumbuk halus kemudian dimasukkan kedalam derigen

- Tambahkan 50 gram gula merah beserta air cucian beras sebanyak 2 liter sebagai prebiotik bakteri MOL Rebung.

- Dihomogenkan

- Ditutup rapat dan diberikan selang kecil yang disambungkan dengan botol yang berisi air.

Mol siap digunakan setelah 15 hari melewati proses fermentasi dan telah matang dengan ciri berwarna kuning kecoklatan dan berbau fermentasi. Adapun cara penggunaannya antara lain:

- Pengomposan. Dapat digunakan sebagai starter kompos. Dengan konsentrasi 1:5 ( 1 litel MOL ditambah 5 liter air). $25 \mathrm{ml}$ MOL dapat digunakan untuk $10 \mathrm{~kg}$ kompos.

- Penggunaan langsung pada tanaman. Penyemprotan dilakukan pada pagi atau sore 
hari dengan konsentrasi 1:15. MOL dapat dipakai sebagai zat perangsang pertumbuhan pada fase vegetatif.

\section{Pembuatan Kompos dari feces sapi}

Pada pembuatan komposini bahan tambahan antara lain tithonia dan MOL rebung. Tithonia ditambahkan sebagai penambah unsur hara kompos.MOL Rebung digunakan untuk mempercepat fermentasi atau dekomposisi. MOL Rebung yang ditambahkan adalah hasil biakan pada poin 1. Unsur pelengkap lainnya antara lain:

1. Alat dan Bahan Untuk $50 \mathrm{~kg}$ kompos.

- $50 \mathrm{~kg}$ feces sapi

- Arang sekam $2.5 \mathrm{~kg}$

- Serbuk gergaji $2.5 \mathrm{~kg}$

- Daun tithonia $11 \mathrm{~kg}$

- Bonggol pisang $1.5 \mathrm{~kg}$.

- Trichoderma $0.12 \mathrm{~kg}$

2. Cara pembuatan

- Campurkan semua bahan menjadi satu

- Masukkan bahan kompos kedalam box fermentasi

- Inkubasi selama $1-2$ minggu.

\section{HASIL DAN PEMBAHASAN}

Dalam kegiatan penyuluhan penambahan tithonia (Thitoniadi versifolia) dan MOL rebung pada pembuatan kompos kotoran sapi simental kelompok tani ternak di Koto Baru Kecamatan Sungai Tarab Kabupaten Tanah Datar dapat dilaksanakan dengan baik dan . masyarakat sangat antusias mengikuti. Mulai dari pemaparan alat dan bahan sampai praktek pembuatan kompos.

Masyarakat Kenagarian Koto Baru Kecamatan Sungai Tarab Kabupaten Tanah Datar sangat menantikan cara pembuatan pupuk komposini. Hal ini dilatar belakangi ketersediaan pupuk komersil yang semakin mahal dan langka. Disamping itu juga masyarakat juga membutuhkan starter pupuk yang berharga murah dan mudah didapatkan seperti MOL Rebung

Keberadaan rebung didapatkan disekitar nagari Koto Baru yang melimpah mengakibatkan harga rebung semakin rendah. MOL rebung dapat menggantikan starter kompos konfensional seperti EM4 dan Stardex. MOL rebung berharga murah dibandingkan starter konfensional tersebut. Dalam pembuatannya MOL Rebung tidak membutuhkan biaya dan tenaga yang besar, sangat cocok diaplikasikan dikanagarian Koto Baru yang sebagian besar penduduknya berpenghasilan sebagai petani. Dalam pebuatan Mol rebung membutuhkan rebung sebagai penyedia bakteri (Bakteri BAL Lactobacillus), gula merah dan air cucian beras Sebagai energi dalam pembuatan mol rebung. Adapun pembuatan MOL Rebung dapat dilihat pada Gambar1.

Proses fermentasi pembuatan MOL Rebung membutuhkan waktu selama 15 hari. Setelah 15 hari maka didapatkan Larutan MOL Rebung yang harus segera diaplikasikan, baik untuk pengomposan atau aplikasi langsung ketanaman.Adapun dalam aplikasikan antara lain: 
- Pengomposan. Dapat digunakan sebagai starter kompos. Dengan konsentrasi1:10 ( 1 litel MOL ditambah 10 liter air).

- Sebagai penyedia N. ditambahkan dengan tithonia.

- Penggunaan langsung padatanaman. Penyemprotan dilakukan pada pagi atau sore hari dengan konsentrasi 1:15. ( 1 liter MOL ditambah 15 liter air). MOL dapat dipakai sebagai zat perangsang pertumbuhan pada fase vegetatif.
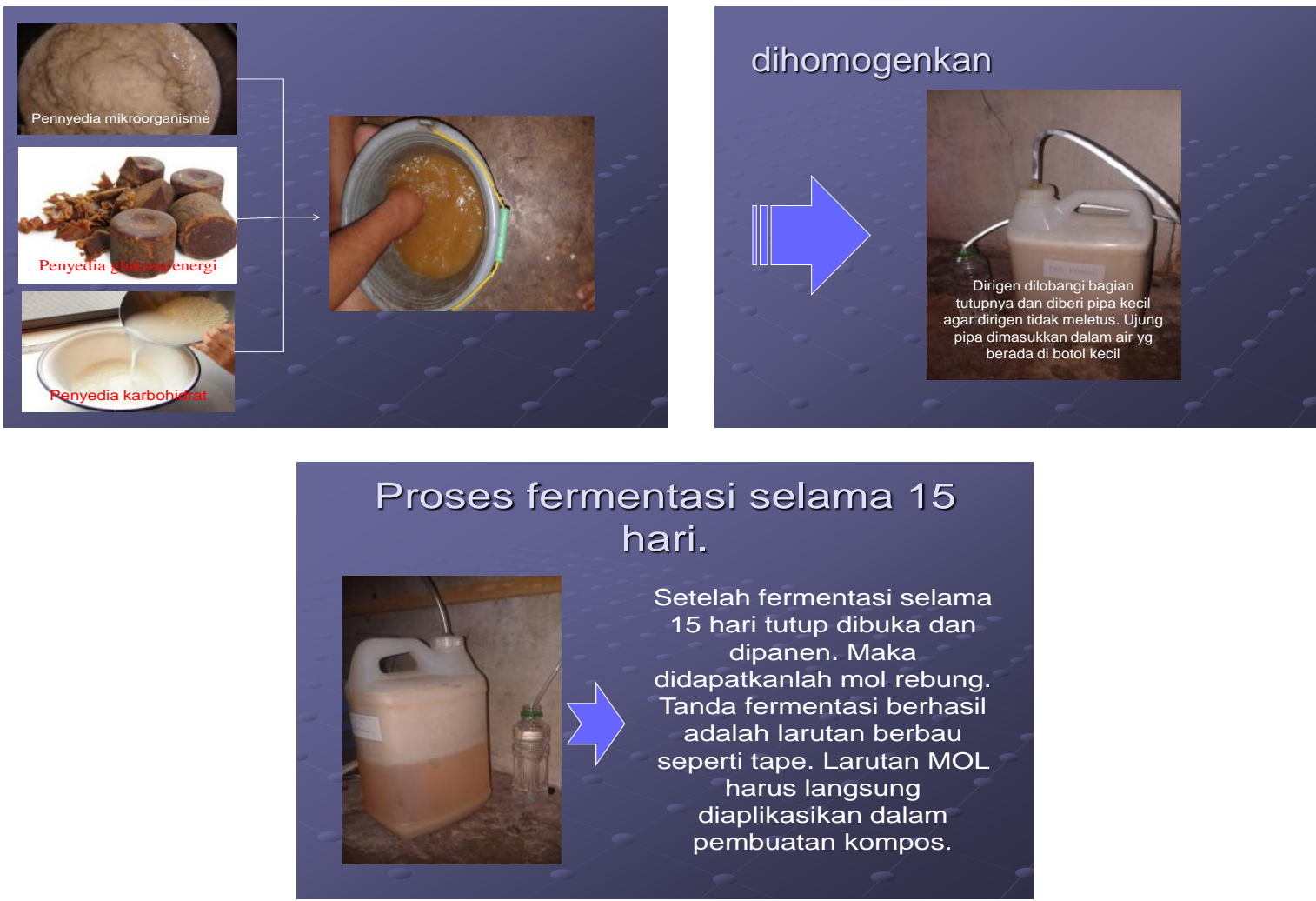

Gambar 1.Proses Pembuatan MOL Rebung

Setelah mendapatkan MOL Rebung, maka starter ini dapat digunakan dalam pembuatan pupuk kompos sebanyak $50 \mathrm{~kg}$. Selain MOL Rebung dalam penyuluhan ini juga memakai tithonia.Tithonia berguna dalam pelengkap unsur hara pupuk kompos.Tithonia didapatkan disekitar jalan tempat penyuluhan.Bonggol pisang juga diperlukan dalam pembuatan komposini.Disamping sebagai penjaga kelembaban, bonggol pisang juga digunakan sebagai MOL lain (mikroorganisme lokal).

Setelah semua bahan terkumpul dan dilakukan percontohan maka dilakukan inkubasi selama 3 minggu. Hasil pengomposan ini sekarang digunakan petani peternak dalam pemupukan tanaman tembakau yang ada dikanagarian dan kelompok peternak peserta penyuluhan

\section{KESIMPULAN DAN SARAN}

Pelaksanaan kegiatan terlaksana dengan baik dan masyarakat sangat antusias dalam kegiatan tersebut. Hal ini selain dikarenakan kelangkaan pupuk, pupuk 
annorganik juga mempunyai harga yang mahal.Pemakaian MOL Rebung juga menolong petani peternak dalam memperoleh starter.Hal ini disebabkan karena starter yang dijual dipasaran dijual dengan harga yang mahal.Sedangkan Mol Rebung tidak membutuhkan biaya dalam pembuatannya .Penyuluhan ini dapat menolong perekonomian masyarakat, karena sebelumnya masyarakat hanya membeli pupuk annorganik yang mahal.

\section{UCAPAN TERIMAKASIH}

Banyak terima kasih kami haturkan kepada LPPM Universitas andalas yang telah membiayai kegiatan yang diselenggarakan dikanagarian Koto Baru Kecamatan Sungai Tarab. Kabupaten Tanah Datar. Banyak terima kasih juga kami haturkan kepada wali Nagari Kotobaru dan Masyarakat atas telah berjalannya penyuluhan ini.

\section{DAFTAR PUSTAKA}

Djuarnani, N. Kristian dan B.S. Setiawan. 2005. Cara Cepat Membuat Kompos. Agromedia Pustaka, Jakarta.

Jama,B.A.,C.A. Palm., R.J.Buresh. A.I. Niang.,C.Gaghego.G.Nziquheba and B.Amadado. 2000. Tithonia Difersifolia as a Green Manure for Improvement of Soil Fertility in Western Kenya. A. Review. Agroforestry System

Syahruddin. F. 2004. Pupuk Kompos. PT. Situjuh Organik Madani. Lima Puluhkota, Sumatera Barat. 